\title{
Biosynthesis and scavenging of pyrimidines by pathogenic mycobacteria
}

\author{
P. R. WHEELER
}

Department of Applied Biology, University of Hull, Hull HU6 7RX, UK

(Received 15 May 1989; revised 29 August 1989; accepted 18 September 1989)

\begin{abstract}
Mycobacterium microti incorporated a wide range of exogenously supplied pyrimidines into its nucleic acids. $M$. avium incorporated a relatively narrow range of pyrimidines but both $M$. avium and $M$. microti when recovered after growth in vivo incorporated a slightly wider range of pyrimidines than the same strains grown in vitro. $M$. microti and $M$. leprae could not take up uridine nucleotides directly but could utilize the pyrimidines by hydrolysing them to uridine and then taking up the uridine. Pyrimidine biosynthesis, judged by the ability to incorporate carbon from $\mathrm{CO}_{2}$ or aspartate into pyrimidines was readily detected in non-growing suspensions of $M$. microti and $M$. avium harvested from Dubos medium, which does not contain pyrimidines. The biosynthetic activity was diminished in mycobacteria grown in vivo when there is likely to be a source of pyrimidines which they might use. Relative activities for pyrimidine biosynthesis de novo in $\mathrm{M}$. microti were 100 for cells isolated from Dubos medium, 6 for cells isolated from Dubos medium containing the pyrimidine cytidine and 11 from cells recovered after growth in mice. In contrast, relative activities for a scavenging reaction, uracil incorporation, were 100, 71 and 59, respectively. Three key enzymes in the pathway of pyrimidine biosynthesis de novo were detected in M. microti and M. avium. Two, dihydroorotate synthase and orotate phosphoribosyltransferase appeared to be constitutive in $M$. microti and $M$. avium. Aspartate transcarbamoylase activity was higher in these mycobacteria grown in vivo than in Dubos medium but it was repressed in $M$. microti or M. avium grown in Dubos medium in the presence of $50 \mu \mathrm{M}$-pyrimidine. Aspartate transcarbamoylase was strongly inhibited by the feedback inhibitors ATP, CTP and UTP. Enzymes for scavenging pyrimidines were detected at low specific activities in all mycobacteria studied. Activities of phosphoribosyltransferases, enzymes that convert bases directly to nucleotides, were not related to the ability of intact mycobacteria to take up pyrimidine bases while activities of pyrimidine nucleoside kinases were generally related to the ability of intact mycobacteria to take up nucleosides. Phosphoribosyltransferase activity for uracil, cytosine, orotic acid and - in organisms grown in Dubos medium with $50 \mu \mathrm{M}$-uridine - thymine, as well as kinases for uridine, deoxyuridine, cytidine and thymidine were detected in M. microti. However, M. avium only contained uracil and orotate phosphoribosyltransferase, uridine, cytidine and thymidine kinase, and additionally deoxyuridine kinase when grown axenically with $50 \mu \mathrm{M}$-uracil, reflecting its more limited abilities in pyrimidine scavenging.
\end{abstract}

\section{Introduction}

Until recently, interest in pyrimidine metabolism in mycobacteria has been somewhat utilitarian: mycobacteria incorporate pyrimidines such as uracil (Benitez et al., 1974; Vejare \& Mahadevan, 1987) and thymidine (Sathish et al., 1985) into their nucleic acids and this activity can be used to estimate the viability or metabolic state of suspensions of mycobacteria. For instance, the rate at which thymidine is incorporated can be used to determine whether Mycobacterium leprae organisms are

Abbreviations: ATCase, aspartate transcarbamoylase; DHO synthase, dihydroorotate synthase. drug-sensitive or drug-resistant (Sathish et al., 1985), are killed in the presence of lymphokines (Prasad et al., 1982), or to evaluate the effectiveness of antimycobacterial agents such as clofazamine and its analogues (Mittal et al., 1985). These methods appear to be very useful since they can be used with mycobacteria inside macrophages, and do not require these microbes, which vary between difficult-to-grow, and in the case of $M$. leprae not yet cultivated axenically, to divide (Barclay \& Wheeler, 1989).

Pyrimidines are also possible substrates for growth of intracellular mycobacteria. They are present, inside host cells, principally as nucleotides, and the main source for mycobacteria would be uridine nucleotides (Lesse $e t$ al., 
1984). Preliminary results suggest that $M$. leprae cannot take up nucleotides directly, but can take up nucleosides and bases (Wheeler, 1989a). One of the objectives of this paper, therefore, is to elucidate how $M$. leprae uses uridine nucleotides for pyrimidine scavenging.

When pyrimidine biosynthesis was investigated in $M$. leprae, no activity could be detected in suspensions of intact $M$. leprae organisms (Wheeler 1989b). However, the enzymes for pyrimidine biosynthesis de novo can be detected in $M$. leprae, suggesting that the pathway does not function in intact $M$. leprae due to feedback inhibition (Wheeler, 1989b). In this paper I have investigated whether the failure of intact $M$. leprae grown in vivo to synthetise pyrimidines de novo is a result generally of growth of mycobacteria in experimental animals by studying biosynthesis in $M$. microti and $M$. avium grown in vivo. Alternatively, the lack of biosynthetic activity in $M$. leprae may simply be a result of doing experiments with mycobacteria that are not growing, so experiments reported here were done with $M$. microti and $M$. avium that are not growing. As $M$. microti and $M$. avium can be grown in vivo, and axenically with and without a source of added pyrimidines, the effect of different growth conditions was investigated - not only on pyrimidine biosynthesis, but also pyrimidine scavenging activities. By studying these two intracellular mycobacteria, it should be possible to interpret at least some of the findings (Wheeler, 1989a,b) on pyrimidine metabolism in $M$. leprae.

\section{Methods}

Mycobacterial strains, growth and harvesting. Comprehensive details are given in a previous paper (Wheeler, 1987a). Briefly, M. leprae was grown in nine-banded armadillos, $M$. microti OV254 in CBA mice and $M$. avium CR1/69 in C57 Black mice. All were harvested and purified by a method including differential centrifugation and density-gradient centrifugation. When suspensions were prepared to make cell-free extracts, they were further purified by partition in an aqueous twophase system (World Health Organization, 1980). Some suspensions were treated with $0.5 \mathrm{M}-\mathrm{NaOH}$ at $25^{\circ} \mathrm{C}$ for $30 \mathrm{~min}$ to abolish any hostderived activities adsorbed to the surface of the bacteria. Infected tissue was stored at $-70{ }^{\circ} \mathrm{C}$ for up to 12 months. However, the values in Table 1 include some obtained using $M$. avium from freshly killed mice. No marked difference in activities were observed between bacteria stored for different periods at $-70^{\circ} \mathrm{C}$ or between bacteria from stored and fresh tissue in the case of $M$. avium. $M$. avium and $M$. microti were also grown (Chadwick, 1982) in Modified Dubos Medium with or without added pyrimidines at $50 \mu \mathrm{M}$, for 16 and $14 \mathrm{~d}$ respectively. All cultures were shaken at $37^{\circ} \mathrm{C}$. Final washed suspensions of all mycobacteria, whether harvested from animal tissue or culture medium, were in buffered Tween $80(0.1 \%$ Tween 80 in $1.5 \mathrm{~mm}-\mathrm{MES}$, $\mathrm{pH} 7 \cdot 0)$.

Radioisotopically labelled substrates. These were supplied at the following specific activities. L-[U-14 $\mathrm{C}] \mathrm{Aspartic}$ acid $\left(270 \mathrm{Ci} \mathrm{mol}{ }^{-1}\right)$; $\mathrm{NaH}^{14} \mathrm{CO}_{3}\left(54 \mathrm{Ci} \mathrm{mol}^{-1}\right) ;\left[6^{-14} \mathrm{C}\right]$ orotic acid $\left(61 \mathrm{Ci} \mathrm{mol}^{-1}\right)$; $\left[2^{-14} \mathrm{C}\right.$ ]uracil $\left(58 \mathrm{Ci} \mathrm{mol}^{-1}\right) ;\left[5,6{ }^{3} \mathrm{H}\right]$ uridine $\left(50 \mathrm{Ci} \mathrm{mmol}^{-1}\right)$; deoxy$\left[6^{-3} \mathrm{H}\right]$ uridine $\left(14 \mathrm{Ci} \mathrm{mmol}^{-1}\right)$; deoxy[5-3 $\left.\mathrm{H}\right]$ cytidine $\left(18 \mathrm{Ci} \mathrm{mmol}^{-1}\right)$; $\left[2{ }^{14} \mathrm{C}\right]$ thymine $\left(51 \mathrm{Ci} \mathrm{mol}^{-1}\right) ;\left[5^{-3} \mathrm{H}\right]$ thymidine $\left(17 \mathrm{Ci} \mathrm{mmol}^{-1}\right)$; [4-14 C]UTP, ammonium salt $\left(60 \mathrm{Ci} \mathrm{mol}^{-1}\right)$; all from Amersham. $\left[2-{ }^{14} \mathrm{C}\right]$ Cytosine $(54 \cdot 6 \mathrm{Ci} \mathrm{mol}-1),\left[2-{ }^{14} \mathrm{C}\right]$ cytidine $\left(43 \mathrm{Ci} \mathrm{mol}^{-1}\right)$ and [U-14 C]UMP, ammonium salt $\left(430 \mathrm{Ci} \mathrm{mol}^{-1}\right)(1 \mathrm{Ci}=37 \mathrm{GBq})$ were from CEA.

Incubations with radioisotopically labelled substrates. Intact mycobacteria $\left(0.6\right.$ to $\left.5 \times 10^{10}\right)$ were incubated at $34^{\circ} \mathrm{C}$ for $24 \mathrm{~h}$ in the following filter-sterilized incubation medium, which did not support growth of the mycobacteria used in this study: $50 \mathrm{~mm}$-HEPES, $5 \mathrm{~mm}-\mathrm{NaCl}, 1$

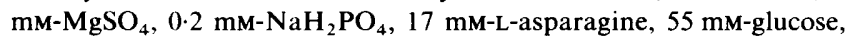
$10 \mu \mathrm{M}$-adenine, $10 \mu \mathrm{M}$-guanine and $10 \mu \mathrm{M}$-hypoxanthine, adjusted to pH 7 with $6 \mathrm{M}-\mathrm{KOH}$. When incubations included [U-14 C]aspartate, Lasparagine could be omitted but this had no effect on the incorporation of aspartate into pyrimidines. Pyrimidine bases and nucleosides were routinely included at $50 \mu \mathrm{M}$, except in experiments shown in Table 7. UTP and UMP were included only at $17 \mu \mathrm{M}$. Aspartate was included at $100 \mu \mathrm{M}, \mathrm{CO}_{2}$ at $1 \mathrm{mM}$. The incubation volume was always $300 \mu \mathrm{l}$ and the following amounts of radiolabelled compounds were included. For experiments summarized in Table 1 : aspartate, $2 \mu \mathrm{Ci}$; $\mathrm{CO}_{2}, 1.67 \mu \mathrm{Ci}$; uracil, $0.9 \mu \mathrm{Ci}$; cytidine, $0.65 \mu \mathrm{Ci}$; orotic acid, $0.9 \mu \mathrm{Ci}$. For experiments summarized in Table 4 : aspartate, $2 \mu \mathrm{Ci} ; \mathrm{CO}_{2}, 1.67 \mu \mathrm{Ci} ;{ }^{3} \mathrm{H}$ labelled pyrimidines, $1 \mu \mathrm{Ci} ;{ }^{14} \mathrm{C}$-labelled pyrimidines, $0.5 \mu \mathrm{Ci}$. UTP and UMP were always included at $0.25 \mu \mathrm{Ci}$ (Table 7). The rationale of using different amounts of radioactivity was to use as much as possible when some fractionation of radioactivity was done, as in Table 1. Therefore, results are presented as percentages of radioactivity supplied: thus for $1 \mu \mathrm{Ci}, 0 \cdot 001 \%$ corresponds to 22 d.p.m. $(1 \mu \mathrm{Ci}=37$ $\mathrm{kBq})$. Controls contained heat-killed $\left(100^{\circ} \mathrm{C}, 15 \mathrm{~min}\right)$ bacteria. Samples $(5 \mu \mathrm{l})$ from all incubations were checked by plating on nutrient agar for contamination. Experimental values from any contaminated incubations were discarded.

Determination of uptake and incorporation. Uptake was determined by collecting incubation mixtures on Whatman GFC filters and washing four times with $15 \mathrm{ml}$ cold, buffered Tween 80 . Filters were dried and radioactivity was determined. Incorporation of label into acidinsoluble material was determined by collecting incubation mixtures on filters and washing as for uptake determinations, then washing three times with ice-cold $5 \%(w / v)$ trichloroacetic acid and once with methanol. Filters were dried and radioactivity was determined.

Determination of incorporation of label into pyrimidines. Nucleic acids were obtained and hydrolysed as described in previous work on purine metabolism (Wheeler, 1987a). Each hydrolysate was dissolved in $100 \mu \mathrm{l} 0 \cdot 1 \mathrm{M}-\mathrm{HCl}$ and applied to a Dowex-50 (200-400 mesh) column $(60 \mathrm{~mm} \times 5 \mathrm{~mm}$ diam.) in $0.1 \mathrm{M}-\mathrm{HCl}$ and eluted with $2.6 \mathrm{ml} 0.1 \mathrm{M}-\mathrm{HCl}$. Authentic labelled materials eluted under these conditions as follows: [U-14 C]aspartate, $0.8 \%$ of radioactivity applied was recovered; $\left[2-{ }^{14} \mathrm{C}\right]$ uracil, $95 \%$ of radioactivity applied was recovered. Thus nearly all the radioactivity that eluted through this type of column was pyrimidine. Only when $<5 \%$ of the hydrolysate eluted through the column would one suspect that a high proportion of the material applied to the column might be amino acids (perhaps from protein contaminating the nucleic acid fraction); this only occurred with hydrolysates from $\boldsymbol{M}$. leprae which had been incubated with [U-14C]aspartate. For other mycobacteria, at least $60 \%$ of the hydrolysate eluted through the column. Assimilation of radioactivity, into nucleotides was detected as described previously (Wheeler, 1987a) by collecting the nucleotides on a Whatman DE-81 filter.

Fractionation of pyrimidines. This was done on selected samples of pyrimidines from $\boldsymbol{M}$. avium and $\boldsymbol{M}$. microti after incubation with $\left[\mathrm{U}-{ }^{14} \mathrm{C}\right.$ ]aspartate. It confirmed that the eluates from Dowex columns contained pyrimidines; the methods are described elsewhere (Wheeler, $1989 a$ ) where it is established that $M$. leprae is capable of interconversion of pyrimidine bases 
Separation of UMP, uracil and uridine. This involved applying $20 \mu \mathrm{l}$ samples of supernate from incubations to a TLC plate (PEI Cellulose $\mathrm{F}$; Merck) and developing in $0.2 \mathrm{M}-\mathrm{LiCl}$. Plates were dried, and examined under a lamp emitting short-wave UV radiation (nominally $254 \mathrm{~nm}$ ); dark areas corresponding to the pyrimidines were identified. These areas were cut-out, and their radioactivity was determined.

Enzyme assays. All were done at $34^{\circ} \mathrm{C}$ with cell-free extracts prepared by ultrasonic disruption of suspensions of bacteria in $5 \mathrm{mM}$ MES plus $1 \mathrm{mM} \mathrm{MgCl}_{2}, \mathrm{pH} 7.0$ (Wheeler \& Gregory, 1980). Units are international units, i.e. 1 unit (U) of activity corresponds to $1 \mu \mathrm{mol}$ substrate used $\min ^{-1}$. Some activities were so low that $\mu \mathrm{U}$ are used in this paper, where $1 \mu \mathrm{U}$ corresponds to 1 pmol substrate used $\min ^{-1}$. Except for aspartate transcarbamoylase (see below) controls included distilled water instead of extract.

Enzymes for pyrimidine biosynthesis de novo. Aspartate transcarbamoylase (ATCase) (EC 2.1.3.2; carbamoyl phosphate:L-aspartate carbamoyl transferase) was assayed by following incorporation of radioactivity into carbamoyl aspartate. The reaction mixture $(25 \mu \mathrm{l})$ included $0.25 \mu \mathrm{Ci} \quad \mathrm{L}-\left[\mathrm{U}-{ }^{14} \mathrm{C}\right]$ aspartate, diluted with unlabelled $\mathrm{L}$ aspartate to $5 \mathrm{~mm}$ (Table 2) or $1 \mathrm{~mm}$ (Table 3); carbamoyl phosphate (Sigma) at $1 \mathrm{~mm}$ (Table 2) or $2.5 \mathrm{~mm}$ (Table 3); and $30 \mathrm{~mm}$-Tris $/ \mathrm{HCl}$, pH 8.5 and cell-free extract.

Samples $(5 \mu \mathrm{l})$ were taken at intervals up to $50 \mathrm{~min}$, mixed with carrier aspartic acid and carbamoyl aspartate ( $20 \mathrm{nmol}$ each), applied to chromogram cellulose TLC plates (Eastman-Kodak) and developed with butan-1-ol/glacial acetic acid/distilled water $(20: 2: 5$, by vol.). Values for activity were calculated by subtracting radioactivity in carbamoyl aspartate in control assays with no carbamoyl phosphate from radioactivity in complete assays including carbamoyl phosphate.

Dihydroorotate synthase (DHO synthase) (EC 3.5.2.3; dihydroorotate hydratase) was assayed in the biosynthetic direction (Fig. 1) as follows. Aspartate transcarbamoylase ( $0 \cdot 1$ unit of Streptococcus faecalis enzyme; Sigma) was mixed with $40 \mu \mathrm{M}$-L-aspartate $\left(10 \mu \mathrm{Ci} \mathrm{m}^{-1}\right)$ and $1 \mathrm{~mm}$-carbamoyl phosphate in $30 \mathrm{~mm}$ Tris $/ \mathrm{HCl}, \mathrm{pH} 8 \cdot 5$. The final volume was $500 \mu \mathrm{l}$. The mixture was incubated for $20 \mathrm{~min}$ at $37^{\circ} \mathrm{C}$ and the reaction stopped by adding $1.5 \mathrm{ml}$ ethanol: the mixture was incubated for a further $15 \mathrm{~min}$ at $37^{\circ} \mathrm{C}$, then dried under vacuum in $100 \mu \mathrm{l}$ portions. The reaction mixture made in this way contained $32 \mu \mathrm{M}$-carbamoyl [U $-{ }^{14} \mathrm{C}$ ]aspartate as judged by the appearance of $80 \%$ of its radioactivity in the spot corresponding to carbamoyl aspartate on TLC. Each portion was stored at $-20^{\circ} \mathrm{C}$ until required then reconstituted by adding dilute acetic acid to $\mathrm{pH} 6.5$ (Wheeler, 1989b) and $20 \mu \mathrm{l}$. Each portion was sufficient for four assays which were done by taking $5 \mu \mathrm{l}$, adding $20 \mu \mathrm{l}$ of mycobacteria extract and incubating at $34^{\circ} \mathrm{C}$. Assays were continued for up to $100 \mathrm{~min}$, with $5 \mu 1$ samples being taken at intervals, mixed with carrier carbamoyl aspartate and dihydroorotate (50 nmol each) and applied to Whatman no. 1 chromatography paper. Descending chromatography was done for $48 \mathrm{~h}$ with propan-2-ol/0.880 $\mathrm{NH}_{3} /$ distilled water $(73: 10: 17$, by vol.) when orotate and dihydroorotate ran together and were separated from aspartate, carbamoyl aspartate and oxaloacetate.

For both the above assays (based on the methods of Kidder $e t$ al., 1976), material was detected on chromatograms by spraying with $0 \cdot 04 \%$ bromocresol blue in ethanol/distilled water $(96: 4, \mathrm{v} / \mathrm{v})$ including sufficient $0 \cdot 1 \mathrm{M}-\mathrm{NaOH}$ just to turn the solution blue.

Orotate phosphoribosyltransferase (EC 2.4.2.10; orotidine-5'phosphate pyrophosphate phosphoribosyltransferase) was assayed in a final volume of $25 \mu \mathrm{l}$ by incubating extracts with [6-14 $\mathrm{C}$ ]orotic acid $(0.061 \mu \mathrm{Ci}, 40 \mu \mathrm{M}), 30 \mathrm{~mm}-\mathrm{Tris} / \mathrm{HCl}, \mathrm{pH} 7.8,2 \mathrm{~mm}-\mathrm{MgCl}_{2}, 1 \mathrm{~mm} \mathrm{2-}$ mercaptoethanol and $50 \mu \mathrm{M}-5^{\prime}$-phosphoribosyl pyrophosphate for up to $100 \mathrm{~min}$. The assay contents were essentially those in the method of Yoshimoto et al. (1978). Samples $(5 \mu \mathrm{l})$ were taken at intervals, mixed with carrier orotate and orotidine monophosphate $(2 \mathrm{nmol}$ each), applied to PEI cellulose TLC plates (Merck; PEI cellulose F) and developed in $0.2 \mathrm{M}-\mathrm{LiCl}$ to separate orotate and orotidine monophosphate.

Enzymes for pyrimidine scavenging. The following enzymes were all assayed at $34^{\circ} \mathrm{C}$ for up to $100 \mathrm{~min}$ : thymidine phosphorylase (EC 2.4.2.4); uracil phosphoribosyltransferase (EC 2.4.2.9); orotate phosphoribosyltransferase (EC 2.4.2.10) (EC 2.4.2.9 or EC 2.4.2.10 include activity for cytosine and thymine); thymidine kinase (EC 2.7.1.21) (also acts on deoxyuridine); uridine kinase (EC 2.7.1.48) (pyrimidine nucleoside kinase: also acts on cytidine); deoxycytidine kinase (EC 2.7.1.74). Methods were based on those of Heyworth et al. (1984) and of Wang \& Chang (1984). Reaction mixtures $(25 \mu \mathrm{l})$ contained labelled substrate and cell-free extract. For phosphoribosyltransferases, assay mixtures included $30 \mathrm{~mm}-\mathrm{Tris} / \mathrm{HCl}, \mathrm{pH} 7.8$, $5 \mathrm{~mm}-\mathrm{MgCl}_{2}, 1 \mathrm{~mm}-5^{\prime}$-phosphoribosyl pyrophosphate, and one of $\left[2 .{ }^{14} \mathrm{C}\right.$ ]uracil $\left(0.058 \mu \mathrm{Ci}\right.$ per assay), $\left[2 .{ }^{14} \mathrm{C}\right]$ cytosine $(0.055 \mu \mathrm{Ci}$ per assay) or $\left[2-{ }^{14} \mathrm{C}\right]$ thymine $(0.055 \mu \mathrm{Ci}$ per assay). These amounts of radiochemical gave a final concentration of pyrimidine base in each assay of $40 \mu \mathrm{M}$.

For pyrimidine nucleoside kinases, assay mixtures included $30 \mathrm{~mm}-$ Tris/ $\mathrm{HCl}, \mathrm{pH} 7.5,5 \mathrm{~mm}-\mathrm{MgCl}_{2}, 5 \mathrm{~mm}-\mathrm{ATP}$ or GTP, $10 \mathrm{~mm}-\mathrm{NaF}$, 1.25 mM-phosphoenolpyruvate, 68 units pyruvate kinase (rabbit muscle; Sigma) $\mathrm{ml}^{-1}$, and one of $\left[5,6^{-3} \mathrm{H}\right]$ uridine, deoxy[6- $\left.{ }^{3} \mathrm{H}\right]$ uridine, deoxy $\left[5-{ }^{3} \mathrm{H}\right]$ cytidine (each $1 \mu \mathrm{Ci}$ per assay), $\left[2{ }^{-14} \mathrm{C}\right]$ cytidine $(0.215 \mu \mathrm{Ci}$ per assay) or $\left[2-{ }^{14} \mathrm{C}\right]$ thymidine $(0.255 \mu \mathrm{Ci}$ per assay). The final concentration of pyrimidine nucleoside in each assay was $200 \mu \mathrm{M}$ so unlabelled substrates had to be added along with $\left[{ }^{3} \mathrm{H}\right]$ substrates in these assays.

For thymidine and uracil phosphorylases, assay mixtures included 30 mM-Tris/HCl, pH 8.3, 5 mM-dithiothreitol, $10 \mathrm{~mm}$-ribose 1-phosphate or deoxyribose 1-phosphate (there was no marked difference in reaction rates between assay mixtures including ribose 1-phosphate or deoxyribose 1 -phosphate) and $\left[2 \cdot{ }^{14} \mathrm{C}\right]$ thymine $(0.275 \mu \mathrm{Ci}$ per assay; $40 \mu \mathrm{M})$ or $\left[5,6^{-3} \mathrm{H}\right]$ uridine $(1 \mu \mathrm{Ci}$ per assay; $40 \mu \mathrm{M})$.

In all assays for scavenging enzymes, $5 \mu \mathrm{l}$ samples were taken at intervals, mixed with carriers (the corresponding base, nucleoside and nucleotides), applied to PEI-cellulose TLC plates (Merck; PEIcellulose $\mathrm{F}$ ), and developed in $0 \cdot 2 \mathrm{M}-\mathrm{LiCl}$.

Additionally, assays with cytosine or cytidine were checked for deaminase activities (EC 3.5.4.1 and EC 3.5.4.5, respectively). Radioactivity in uracil and uridine was determined in $5 \mu 1$ samples as described previously (Wheeler, 1989a) during assays for cytosine phosphoribosyltransferase or cytidine kinase. CMP and UMP were separated by applying $5 \mu \mathrm{l}$ samples to PEI-cellulose TLC plates, developing first in distilled water, cutting out the areas including bases and nucleosides $\left(R_{F}\right.$ values $\left.>0.7\right)$, then developing the nucleotides, which had barely migrated from the origin, in the same direction in propan-2-ol/5 $\mathrm{M}-\mathrm{HCl}(10: 7$, by vol.).

Determination of radioactivity. Spots on developed chromatograms were cut out and placed in scintillation vials; $0.1 \mathrm{M}-\mathrm{HCl}(150 \mu \mathrm{l})$ was then added. After $10 \mathrm{~min}$ Bray's scintillation fluid was added and radioactivity determined by liquid-scintillation counting.

Expression of values in Results, and statistical methods. All the values presented for activities were obtained by calculating the mean and standard error of the mean of all the results from incubations or enzyme assays with live bacteria or cell-free extracts done to determine each activity, then subtracting the mean of all the results of controls (see above) for each corresponding activity. Sometimes this gave values of zero or below zero for activities; these are all presented as zero in the Tables, with the range of results with the mean of the control results subtracted instead of the standard error of the mean. Student's $t$-test was done using the results from incubations or enzyme assays with live 
bacteria or cell-free extracts to test whether the mean values obtained from them were significantly different from zero, and where indicated in the test from each other.

\section{Results}

\section{Pyrimidine biosynthesis in intact mycobacteria}

In contrast to $M$. leprae, pyrimidine biosynthesis de novo could be detected in both $M$. microti and $M$. avium grown in vivo (Table 1). However, the rates of biosynthesis were considerably lower in mycobacteria grown in vivo (Table 1), than in those grown in Dubos medium without added pyrimidines.

In all the experiments reported in this paper, mycobacteria were harvested from the growth media mentioned in the Tables and incubated in a standard incubation buffer (described in Methods) in which they did not grow. Thus, as for $M$. leprae (Wheeler, 1989b), these measurements of pyrimidine biosynthesis are for non-growing mycobacteria. The metabolic state and proportion of viable organisms could vary considerably in suspensions of organisms harvested from different growth media, as well as experimental animals. Such variation is extremely difficult to control in host-grown bacteria. Thus the rates of pyrimidine biosynthesis and scavenging were compared in Table $1:$ if both activities varied in the same manner, they would be reflecting the quality of the organisms in the suspensions, but if differences in biosynthetic and scavenging activities occurred, there would be some metabolic significance.

In $M$. microti, pyrimidine biosynthesis de novo, as shown by incorporation of aspartate into pyrimidines, occurred at a rate nine times slower in $M$. microti grown in mice than in $\boldsymbol{M}$. microti grown in Dubos medium. Growth in Dubos medium with added pyrimidines had a similar effect (Table 1). In contrast, the rate of incorporation of pyrimidines was similar regardless of how $M$. microti was grown, being only 1.7 times slower for uracil in $M$. microti grown in mice than in $M$. microti grown in Dubos medium (Table 1). Thus pyrimidine biosynthesis de novo is considerably diminished in $M$. microti when exogenous pyrimidines are available. In $M$. avium grown in vivo compared with $M$. avium grown in Dubos medium, the rate of biosynthesis de novo was 3.5 times slower while the rate of incorporation of uracil and cytidine was 1.8 and 1.7 times slower, respectively (Table 1). Similar but clearer effects were seen in $\boldsymbol{M}$. avium grown in the presence of pyrimidines, when the rate of biosynthesis de novo decreased, while the rate of incorporation increased or was not significantly different when compared with rates observed in $M$. avium grown in Dubos medium only (Table 1). The differential decreases in biosynthesis de novo (Table 1) suggest its down-regulation in mycobacteria grown in vivo, or in the presence of pyrimidines.

Table 1. Pyrimidine synthesis and scavenging - incorporation of label into isolated nucleic acids

Incubations were at $34{ }^{\circ} \mathrm{C}$ and included 0.8 to $2.4 \times 10^{10}$ organisms. Two (for orotic acid) or two to five incubations were done for each result, except where no SEM value is given; then, only one incubation was done for each result. Usually, each of these incubations was from a separate isolate or culture. All values are the percentage of radioactivity supplied that was incorporated in $24 \mathrm{~h}$ by $10^{10}$ organisms, $\pm \mathrm{SEM}$ (if $>$ one incubation). ND, Not done.

\begin{tabular}{|c|c|c|c|c|}
\hline \multirow[b]{3}{*}{$\begin{array}{l}{ }^{14} \mathrm{C} \text {-Labelled substrate } \\
\text { in incubation medium }\end{array}$} & \multicolumn{4}{|c|}{ Incorporation into pyrimidines in nucleic acids of $M$. microti } \\
\hline & \multicolumn{4}{|c|}{ Growth medium: } \\
\hline & Dubos & $\begin{array}{c}\text { Dubos }+ \\
50 \mu \mathrm{M} \text {-uridine }\end{array}$ & $\begin{array}{c}\text { Dubos }+ \\
50 \mu \mathrm{M} \text {-cytidine }\end{array}$ & Mice (CBA) \\
\hline \multirow{4}{*}{$\begin{array}{l}{\left[\mathrm{U}-1^{4} \mathrm{C}\right] \text { Aspartate }} \\
{\left[6-{ }^{14} \mathrm{C}\right] \text { Orotic acid }} \\
{\left[2-^{14} \mathrm{C}\right] \text { Uracil }} \\
{\left[2-{ }^{4} \mathrm{C}\right] \mathrm{Cytidine}}\end{array}$} & $0.258 \pm 0.033$ & $0 \cdot 044 \pm 0 \cdot 003$ & $0.016 \pm 0.002$ & $0.028 \pm 0.002$ \\
\hline & $0 \cdot 121 \pm 0 \cdot 005$ & ND & ND & $0 \cdot 114$ \\
\hline & $1.722 \pm 0.045$ & $0 \cdot 931 \pm 0 \cdot 102$ & $1.232 \pm 0.061$ & $1.005 \pm 0.172$ \\
\hline & $0 \cdot 231 \pm 0.076$ & $0 \cdot 321$ & $0 \cdot 150 \pm 0 \cdot 004$ & ND \\
\hline \multirow[b]{3}{*}{$\begin{array}{l}{ }^{14} \mathrm{C} \text {-Labelled substrate } \\
\text { in incubation medium }\end{array}$} & \multicolumn{4}{|c|}{ Incorporation into pyrimidines in nucleic acids of $\boldsymbol{M}$. avium } \\
\hline & \multicolumn{4}{|c|}{ Growth medium: } \\
\hline & Dubos & $\begin{array}{c}\text { Dubos }+ \\
50 \mu \mathrm{M} \text {-uridine }\end{array}$ & $\begin{array}{c}\text { Dubos }+ \\
50 \mu \mathrm{M} \text {-cytidine }\end{array}$ & $\begin{array}{c}\text { Mice } \\
\text { (C57 Black) }\end{array}$ \\
\hline$\left[\mathrm{U}-{ }^{14} \mathrm{C}\right]$ Aspartate & $0.031 \pm 0.005$ & $0.016 \pm 0.004$ & $0.006 \pm 0.003$ & $0.009 \pm 0.002$ \\
\hline$\left[2-{ }^{14} \mathrm{C}\right]$ Uracil & $0.646 \pm 0.177$ & $1.515 \pm 0.026$ & $0.604 \pm 0.047$ & $0.347 \pm 0.025$ \\
\hline$\left[2-^{14} \mathrm{C}\right]$ Cytidine & $0.344 \pm 0.054$ & $0.700 \pm 0.068$ & $0.380 \pm 0.015$ & $0 \cdot 195$ \\
\hline
\end{tabular}




\section{Enzymes of pyrimidine biosynthesis}

Each of the first two enzymes unique to the pathway of pyrmidine biosynthesis de novo were detected in extracts of host-grown $M$. avium and $M$. microti at similar activities (Table 2). These were about five times greater than in $M$. leprae for ATCase and about twelve times greater than in $M$. leprae for DHO synthase (for activities in $M$. leprae, see Wheeler, 1989b). ATCase is present at higher specific activity in extracts of mouse-grown $M$. microti or $M$. avium (Table 2) than in these mycobacteria grown in Dubos medium, yet the rate of pyrimidine biosynthesis de novo is considerably lower in intact mycobacteria recovered after growth in mice than recovered after growth in Dubos medium (Table 1). ATCase activity was repressed in $M$. microti and $M$. avium grown in Dubos medium with added pyrimidines to below the specific activity detected in extracts of $M$. leprae prepared from $M$. leprae organisms which, when intact, did not synthesize pyrimidines de novo (Wheeler, $1989 b$ ). Yet pyrimidine biosynthesis could be detected in intact $M$. microti and $M$. avium grown in the medium with added pyrimidine (Table 1). Surprisingly, even when ATCase was below the limit of detection in extract of $M$. avium (Table 2), pyrimidine biosynthesis could be detected (albeit at a very low rate) in intact $M$. avium grown in corresponding conditions (Table 1). Although repression of ATCase activity seems to occur in $M$. microti and $M$. avium when grown in Dubos medium to which pyrimidines are added, no such repression appears in these mycobacteria grown in vivo (Table 1).

The effect of nucleotides on ATCase was tested, as they act as important feedback inhibitors of this enzyme. At $2.5 \mathrm{mM}$, inhibition by UTP and CTP was almost complete while inhibition by ATP was 70 to $90 \%$, for ATCase from both $M$. microti and $M$. avium (Table 3), as well as $M$. leprae (Wheeler, 1989 b). The effect of nucleotides on ATCase from $M$. microti grown in Dubos medium with added uridine was also tested as the specific activity of the enzyme is considerably diminished when the bacteria are grown in the presence of uridine. However, the effect of nucleotides on ATCase was similar in $M$. microti grown in either medium.

\section{Pyrimidine scavenging in intact mycobacteria}

Like $M$. leprae (Wheeler, 1989a), intact $M$. microti organisms incorporated a wide range of substrates into acid-insoluble material (Table 4). There were few clear differences between the activities of $M$. microti grown in vivo or in Dubos medium. Only orotic acid was incorporated considerably more rapidly into axenically

Table 2. Enzymes for pyrimidine biosynthesis de novo

Activities were determined in extracts from two or three different suspensions of bacteria from each medium. Each value represents the mean of three to six determinations \pm SEM. No differences in activities were observed between desalted extracts (by ultrafiltration through cones with cut-off $M_{\mathrm{r}}=25000$ ) and extracts that were not desalted. For ATCase, the substrate, L-aspartate was at $5 \mathrm{mM}$; for DHO synthase, the substrate, carbamoyl aspartate, was at $32 \mu \mathrm{M}$.

\begin{tabular}{|c|c|c|c|c|}
\hline \multicolumn{2}{|c|}{ Cell-free extract from: } & \multicolumn{3}{|c|}{$\begin{array}{l}\text { Enzyme specific activity } \\
{\left[\mu \mathrm{U}(\mathrm{mg} \text { protein })^{-1}\right]}\end{array}$} \\
\hline Organism & $\begin{array}{l}\text { Growth } \\
\text { medium }\end{array}$ & ATCase & DHO synthase & $\begin{array}{c}\text { Orotate } \\
\text { phosphoribosyl- } \\
\text { transferase }\end{array}$ \\
\hline M. microti & $\begin{array}{l}\text { Mice* } \\
\text { Dubos } \\
\text { Dubos }+50 \mu \mathrm{M}- \\
\text { uridine }\end{array}$ & $\begin{array}{l}1590 \pm 550 \\
1230 \pm 281 \\
287 \pm 125\end{array}$ & $\begin{array}{l}13 \pm 3 \\
24 \pm 2 \\
38 \pm 4\end{array}$ & $\begin{array}{l}76 \pm 3 \\
67 \pm 5 \\
58 \pm 9\end{array}$ \\
\hline M. avium & $\begin{array}{l}\text { Mice* } \\
\text { Dubos } \\
\text { Dubos }+50 \mu \mathrm{M}- \\
\text { cytidine } \\
\text { Dubos }+50 \mu \mathrm{M}- \\
\text { uracil }\end{array}$ & $\begin{array}{c}1663 \pm 298 \\
768 \pm 190 \\
0(-30 \text { to } 30) \dagger \\
0(-30 \text { to } 40) \dagger\end{array}$ & $\begin{array}{r}15 \cdot 0 \pm 0.5 \\
10 \cdot 1 \pm 1 \cdot 6 \\
4 \cdot 4 \pm 1 \cdot 1 \\
10.6 \pm 3.5\end{array}$ & $\begin{array}{c}70 \pm 25 \\
69 \pm 5 \\
\text { ND } \\
\quad \text { ND }\end{array}$ \\
\hline
\end{tabular}

ND, Not done.

* Activity in extracts from $\mathrm{NaOH}$-treated mycobacteria was not markedly different from activity in extracts from untreated mycobacteria; values represent results obtained with both extracts.

$\uparrow$ Limit of detection about $20 \mu \mathrm{U}$ (mg protein $)^{-1}$ for ATCase, $0.2 \mu \mathrm{U}$ (mg protein) ${ }^{-1}$ for DHO synthase, and $4 \mu \mathrm{U}$ (mg protein $)^{-1}$ for orotate phosphoribosyltransferase. 
Table 3. Effect of feedback inhibitors on ATCase

Assays contained $1 \mathrm{~mm}$-L-aspartate and $2.5 \mathrm{~mm}$-carbamoyl phosphate. Activities were determined in extracts from two different suspensions of bacteria (neither treated with $\mathrm{NaOH}$ ) from each medium, in duplicate with each extract, and are expressed as mean, relative activities where 100 is the activity with no nucleotide inhibitor added. (Specific activities in these assays with no inhibition are shown below.) The range of relative activities was always the values presented $< \pm 12$.

\begin{tabular}{|c|c|c|c|c|c|c|c|c|}
\hline \multirow{2}{*}{\multicolumn{2}{|c|}{ Cell-free extract from: }} & \multicolumn{6}{|c|}{ Relative activity in the presence of: } & \multirow[b]{3}{*}{$\begin{array}{l}\text { Specific } \\
\text { activity* }\end{array}$} \\
\hline & & \multicolumn{2}{|c|}{ ATP } & \multicolumn{2}{|c|}{ UTP } & \multicolumn{2}{|c|}{ CTP } & \\
\hline Organism & $\begin{array}{l}\text { Growth } \\
\text { medium }\end{array}$ & $0 \cdot 2 \mathrm{mM}$ & $2 \cdot 5 \mathrm{mM}$ & $0 \cdot 2 \mathrm{~mm}$ & $2 \cdot 5 \mathrm{mM}$ & $0.2 \mathrm{mM}$ & $2.5 \mathrm{mM}$ & \\
\hline \multirow[t]{2}{*}{ M. microti } & Dubos & 67 & 11 & 54 & 4 & 76 & 6 & $599 \pm 35$ \\
\hline & $\begin{array}{l}\text { Dubos }+50 \mu \mathrm{M}- \\
\text { uridine }\end{array}$ & 61 & 18 & 49 & 3 & 66 & 6 & $154 \pm 30$ \\
\hline M. avium & Dubos & ND & 30 & ND & 10 & ND & 0 & $312 \pm 42$ \\
\hline
\end{tabular}

ND, Not done.

* L-Aspartate is at the lower concentration here; values given in Table 2 are presented with carbamoyl phosphate at the lower concentration.

Table 4. Incorporation of pyrimidines and their precursors into intact mycobacteria

Incubations were at $34^{\circ} \mathrm{C}$ and included 0.6 to $1.4 \times 10^{10}$ organisms, either $M$. microti or $M$. avium. Two to eight incubations were done for each result, usually in duplicate from separate isolates or cultures. All values are the percentage of radioactivity supplied that was incorporated in $24 \mathrm{~h}$ by $10^{10}$ organisms, \pm SEM or range of values for zero activity.

\begin{tabular}{|c|c|c|c|c|}
\hline \multirow{3}{*}{$\begin{array}{l}\text { Labelled substrate in } \\
\text { incubation medium }\end{array}$} & \multicolumn{4}{|c|}{ Incorporation into acid-insoluble material } \\
\hline & \multicolumn{2}{|c|}{ Growth medium for $M$. microti } & \multicolumn{2}{|c|}{ Growth medium for $\boldsymbol{M}$. avium } \\
\hline & Dubos & Mice (CBA) & Dubos & Mice (C57 Black) \\
\hline${ }^{14} \mathrm{CO}_{2}$ & $0.075 \pm 0.005^{*}$ & $0.009 \pm 0.003^{*}$ & $0.010 \pm 0.001^{*}$ & $0.002 \pm 0.001 * \ddagger$ \\
\hline$\left[\mathrm{U}-{ }^{-14} \mathrm{C}\right]$ Aspartate & $0.893 \pm 0.054$ & $1 \cdot 100 \pm 0 \cdot 160 \dagger$ & $0.318 \pm 0.068$ & $0.212 \pm 0.001^{*}$ \\
\hline$\left[6^{-14} \mathrm{C}\right]$ Orotic acid & $1 \cdot 721 \pm 0 \cdot 318$ & $0 \cdot 257 \pm 0 \cdot 014$ & $0(-0.04$ to 0.019$)$ & $0.012 \pm 0.011 \ddagger$ \\
\hline$\left[2-{ }^{14} \mathrm{C}\right]$ Uracil & $2.116 \pm 0.009$ & $1 \cdot 158 \pm 0.046 \dagger$ & $0.845 \pm 0.061$ & $0.522 \pm 0.091 \dagger$ \\
\hline$\left[5,6-{ }^{3} \mathrm{H}\right]$ Uridine & $0.608 \pm 0.055$ & $0.570 \pm 0.061 \dagger$ & $0.030 \pm 0.016 \ddagger$ & $0.057 \pm 0.002$ \\
\hline Deoxy $\left[6^{-3} \mathrm{H}\right]$ uridine & $0.007 \pm 0.024 \ddagger$ & $0.092 \pm 0.015$ & $0.001 \pm 0.006 \ddagger$ & $0(-0.007$ to -0.001$)$ \\
\hline$\left[2-{ }^{14} \mathrm{C}\right]$ Cytosine & $0 \cdot 360 \pm 0.136$ & $0.635 \pm 0.045$ & $0(-0.286$ to 0.024$)$ & $0.017 \pm 0.009 \ddagger$ \\
\hline$\left[2-{ }^{14}\right.$ C $]$ Cytidine & $1.095 \pm 0.273$ & $0.914 \pm 0.302$ & $0 \cdot 607 \pm 0.121$ & $0.558 \pm 0.171 \dagger$ \\
\hline Deoxy $\left[5^{-3} \mathrm{H}\right]$ cytidine & $0.040 \pm 0.009$ & $0.339 \pm 0.012$ & $0.005 \pm 0.015 \ddagger$ & $0(-0.011$ to 0.004$)$ \\
\hline$\left[2-{ }^{14} \mathrm{C}\right]$ Thymine & $0.431 \pm 0.014$ & $0.543 \pm 0.002 \dagger$ & $0.040 \pm 0.019$ & $0.116 \pm 0.024 \dagger$ \\
\hline$\left[5-{ }^{3} \mathrm{H}\right]$ Thymidine & $0.058 \pm 0.009$ & $0.193 \pm 0.005 \dagger$ & $0.003 \pm 0.001 \ddagger$ & $0.058 \pm 0.026$ \\
\hline
\end{tabular}

* Radioactivity determined in hydrolysed nucleic acid fraction.

$\dagger$ When mycobacteria harvested from mice were treated with $0.5 \mathrm{M}-\mathrm{NaOH}$ at $25^{\circ} \mathrm{C}$ for $30 \mathrm{~min}$, incorporation was observed at 70 to $110 \%$ of the rates reported above

$\ddagger$ Not significantly $(P>0 \cdot 05)$ above zero.

grown $M$. microti, yet even this result is difficult to interpret, as the amount of label appearing in pyrimidines from hydrolysed nucleic acids was similar for $M$. microti grown in vivo and axenically (Table 1). Yields of label in the pyrimidines from hydrolysed nucleic acids (Table 1) varied considerably - from 25 to $85 \%$ of the label incorporated in acid-insoluble material (Table 4) - except for orotate in $M$. microti grown in Dubos medium when the yield was exceptionally low at $7 \%$. The activities that were notably enhanced in $M$. microti grown in mice were incorporation of pyrimidine deoxynucleosides, in particular deoxyuridine (Table 4). In contrast, $M$. avium only incorporated a relatively narrow range of pyrimidines (Table 4). Incorporation of $>1000$ 
c.p.m. $10^{10} M$. avium organisms in $24 \mathrm{~h}$ (i.e. readily detectable activity) was only obtained with uracil and cytidine, and barely with thymine. The only clear differences in the activities in M. avium grown in vivo and in vitro were the higher rate of incorporation of thymine in $M$. avium grown in vivo and the detection of thymidine incorporation only in $M$. avium grown in vivo. It was the poor incorporation of uridine that dictated the use of uracil rather than uridine as a pyrimidine which was added to Dubos medium in experiments (Tables 1, 2, 5 and 6) with $M$. avium. Before this observation, uridine was preferred as it is much more soluble than uracil and more concentrated stock solutions could be made. However, when a single batch of $M$. microti was grown in Dubos medium $+50 \mu \mathrm{M}$-uracil (results not shown in detail), similar activities of incorporation of labelled substrates into pyrimidines from hydrolysed nucleic acids (Table 1), ATCase (Table 2), uridine kinase (Table 5) and uracil phosphoribosyltransferase (Table 6) were obtained to those found in $M$. microti grown in Dubos medium $+50 \mu \mathrm{M}$-uridine.

The subject of pyrimidine scavenging by intact mycobacteria will be referred to throughout the next section on enzymes, as one of the major objectives of studying the enzymes was to find out whether it is their distribution, and control, that determines which pyrimidines mycobacteria can scavenge.

\section{Enzymes for pyrimidine scavenging}

The enzymes shown in Tables 5 and 6 (and, for the uracil base, in Fig. 1) are those involved in the first step in using sources of the pyrimidine ring for nucleic acid jiosynthesis. Enzymes for interconversion of one pyrim idine base to another were found previously in $M$. leprat (Wheeler, $1989 a$ ), but of such enzymes only cytosine and cytidine deaminases were sought in $M$. microti and $M$. avium. Their specific activities are not shown in detail, but they were present at sufficient activity to convert up to $5 \%$ of the cytosine/cytidine to uracil/uridine in $1 \mathrm{~h}$ in assays for cytosine phosphoribosyltransferase activity and cytidine kinase activity. However, the radioactivity in nucleotides in these assays with extracts of $M$. leprae, and $M$. microti and $M$. avium both grown in vivo, increased with time only in CMP, and not UMP, indicating that where cytosine phosphoribosyltransferase (Table 6) and cytidine kinase (Table 5) activities are claimed (for $M$. leprae: Wheeler, 1989a) they are present, and not a result of deamination followed by conversion of the uracil or uridine to UMP. Many specific activities in all mycobacteria studied were very low but by extending incubation times for enzyme assays to $100 \mathrm{~min}$, and by including mycobacterial protein at $4 \mathrm{mg} \mathrm{ml}^{-1}$, activity at about $0.2 \mathrm{pmol} \mathrm{min}^{-1}$ (mg protein) $)^{-1}$ could be detected. In practice, the lowest specific activity detected which was significantly above zero was $0.6 \mathrm{pmol} \mathrm{min}^{-1}$ (mg protein $^{-1}$ (deoxyuridine kinase in $M$. leprae; Wheeler, 1989a).

Generally, pyrimidine nucleoside kinases (Table 5) were found in extracts of mycobacteria which, when intact, incorporated the corresponding nucleoside. For example, deoxyuridine was incorporated by intact $M$. microti grown in vivo, but not in Dubos medium, and deoxyuridine kinase activity was detected in extracts

Table 5. Enzymes of pyrimidine scavenging: kinases

Activities were determined in extracts from two different suspensions of mycobacteria. Each value, expressed as $\mu \mathrm{U}(\mathrm{mg}$ protein $)^{-1}$, represents the mean of three to seven determinations \pm SEM or range of values for zero activity. No differences in activities were observed between desalted extracts (by ultrafiltration through cones with cut-off $\left.M_{\mathrm{r}}=25000\right)$ and extracts that were not desalted.

\begin{tabular}{|c|c|c|c|c|c|c|}
\hline \multirow{2}{*}{\multicolumn{2}{|c|}{ Cell-free extract from: }} & \multicolumn{5}{|c|}{ Substrate $(200 \mu \mathrm{M})$ for enzyme } \\
\hline & & \multirow[b]{2}{*}{ Uridine } & \multirow[b]{2}{*}{ uridine } & \multirow{2}{*}{$\begin{array}{l}\text { Deoxy- } \\
\text { Cytidine }\end{array}$} & \multirow[b]{2}{*}{ cytidine } & \multirow{2}{*}{$\begin{array}{c}\text { Deoxy- } \\
\text { Thymidine* }\end{array}$} \\
\hline Organism & Growth medium & & & & & \\
\hline \multirow[t]{3}{*}{ M. microti } & Mice† & $14 \pm 7$ & $34 \pm 13$ & $40 \pm 16$ & $6 \pm 4 \ddagger$ & $12 \pm 3$ \\
\hline & Dubos & $6 \pm 3$ & $0(-\overline{4}$ to 0$)$ & $10 \pm 4$ & $0(-8$ to 4$)$ & $7 \pm 3$ \\
\hline & Dubos $+50 \mu \mathrm{M}$-uridine & $19 \pm 1$ & $8 \pm 5 \ddagger$ & $31 \pm 15$ & $0(-5$ to 2$)$ & $11 \pm 3$ \\
\hline \multirow[t]{4}{*}{ M. avium } & Mice $\dagger$ & $29 \pm 7$ & $0(-2$ to 3$)$ & $13 \pm 5$ & $0(-4$ to 5$)$ & $6 \pm 2$ \\
\hline & Dubos & $10 \pm 3$ & $0(-3$ to 3$)$ & $7 \pm 2$ & $0(-3$ to 1$)$ & $3 \pm 4 \ddagger$ \\
\hline & Dubos $+50 \mu \mathrm{M}$-cytidine & $5 \pm 2$ & $0(-2$ to 3$)$ & $8 \pm 1$ & $0(-2$ to 2$)$ & $8 \pm 3$ \\
\hline & Dubos $+50 \mu \mathrm{M}$-uracil & $16 \pm 5$ & $5 \pm 2$ & $6 \pm 3$ & $0(-2$ to 2$)$ & $0(-5$ to 4$)$ \\
\hline
\end{tabular}

* ATP dependent; no activity with GTP. All other kinases were GTP dependent - their activity with ATP was $<20 \%$ (i.e. usually undetectable) of that with GTP.

$\dagger$ Activity in extracts from $\mathrm{NaOH}$-treated mycobacteria was not markedly different from activity in extracts from untreated mycobacteria; values represent results obtained with both extracts.

$\ddagger$ Not significantly above zero $(P>0.05)$. 
Table 6. Enzymes for scavenging pyrimidine bases

Activities were determined in extracts from two different suspensions of mycobacteria. Each value, expressed as $\mu \mathrm{U}$ ( $\mathrm{mg}$ protein $)^{-1}$, represents the mean of three to seven determinations \pm SEM or range of values for zero activity. No differences in activities were observed between desalted extracts (by ultrafiltration through cones with cut-off $M_{r}=$ 25000) and extracts that were not desalted.

\begin{tabular}{|c|c|c|c|c|c|c|}
\hline \multicolumn{2}{|c|}{ Cell-free extract from: } & \multicolumn{3}{|c|}{$\begin{array}{l}\text { Substrate }(40 \mu \mathrm{M}) \\
\text { for phosphoribosyltransferase* }\end{array}$} & \multicolumn{2}{|c|}{$\begin{array}{c}\text { Substrate }(40 \mu \mathrm{M}) \\
\text { for nucleoside phosphorylase } \uparrow\end{array}$} \\
\hline Organism & Growth medium & Uracil & Cytosine & Thymine & Thymine & Uracil \\
\hline \multirow[t]{3}{*}{ M. microti } & Mice & $15 \pm 2$ & $3.9 \pm 1 \cdot 3$ & $0(-1.5$ to -0.4$)$ & $250 \pm 52$ & $44 \pm 2$ \\
\hline & Dubos & $143 \pm 4$ & $0.5 \pm 0.8 \S$ & $0(-0.5$ to 0.6$)$ & $190 \pm 27$ & $27 \pm 7$ \\
\hline & Dubos $+50 \mu \mathrm{M}$-uridine & $249 \pm 4$ & $1.9 \pm 0.7$ & $1.4 \pm 0.5$ & $\mathrm{ND}$ & ND \\
\hline \multirow[t]{4}{*}{ M. avium } & Mice & $16 \pm 2$ & $0(-2$ to 3$)$ & $0(-3$ to -1$)$ & $90 \pm 18$ & $49 \pm 6$ \\
\hline & Dubos & $29 \pm 2$ & $0(-2$ to 0$)$ & $0(-1$ to 0$)$ & $110 \pm 30$ & $38 \pm 3$ \\
\hline & Dubos $+50 \mu \mathrm{M}$-cytidine & $18 \pm 2$ & $0(-5$ to 2$)$ & $0(-1$ to +1$)$ & ND & ND \\
\hline & Dubos $+50 \mu \mathrm{M}$-uracil & $18 \pm 2$ & $0(-2$ to 0$)$ & $0(-3$ to -1$)$ & ND & $50 \pm 6$ \\
\hline
\end{tabular}

\footnotetext{
ND, Not done.

* See Table 2 for orotate phosphoribosyltransferase which was always detected when sought.

$\dagger$ Cytosine phosphorylase activity was not detected in any extract.

$\ddagger$ Activity in extracts from $\mathrm{NaOH}$-treated mycobacteria was not markedly different from activity in extracts from untreated mycobacteria; values represent results obtained with both extracts.

$\S$ Not significantly above zero $(P>0.05)$.
}

from M. microti only when the organisms were grown in vivo. When kinases were not detected (Table 5), nucleosides were not incorporated, with the exception of deoxycytidine at a very low rate into $M$. microti grown in Dubos medium (Table 4). The mechanism for, and significance of this deoxycytidine incorporation is not discernible from these studies.

A general impression from Table 5 is that pyrimidine nucleoside kinases were present at higher activities in host-grown mycobacteria than in the same strains grown in Dubos medium. The most striking examples are cytidine and deoxycytidine kinases in $M$. microti and uridine kinase in $M$. avium. The limited attempts to stimulate these activities during axenic growth by adding pyrimidines to the medium were, however, inconclusive (Table 5); any stimulation of uridine kinase activity (in $M$. microti or $M$. avium) was marginal. Only cytidine kinase in $M$. microti was markedly stimulated - an observation perhaps made possible by this being one of the few activities which were at all easy to detect.

The pyrimidine base which was most readily utilized by all three mycobacteria studied was uracil (Table 4). Uracil phosphoribosyltransferase was readily detectable in extracts of $M$. microti and $M$. avium, and present at lower activity [ $3 \mu \mathrm{U}(\mathrm{mg} \text { protein })^{-1}$ ] in extracts of $M$. leprae (Wheeler, 1989a). This enzyme allows direct conversion of uracil to UMP (Fig. 1) but an alternative pathway is possible in all three mycobacteria (Fig. 1) as uridine phosphorylase (Table 6) and uridine kinase
(Table 5) are also present (for $M$. leprae, see Wheeler, 1989a). Metabolic control of uracil phosphoribosyltransferase is apparent, particularly in $M$. microti, as it is present at diminished activities in mycobacteria grown in vivo (Table 6), corresponding with the slightly slower rates of uracil incorporation in $M$. avium and $M$. microti grown in vivo compared with $M$. avium and $M$. microti grown in Dubos medium (Table 4).

However, activity of phosphoribosyltransferase for different bases in extracts does not correspond to the ability of intact mycobacteria to take up pyrimidine bases (Table 4). In particular, thymine is taken up and incorporated into nucleic acid by suspensions of mycobacteria (see Table 4) lacking any direct activity for converting thymine to a nucleotide. Only when $M$. microti was grown in the presence of uridine was any thymine phosphoribosyltransferase activity detected. Using the commercially available 5'-phosphoribosylpyrophosphate, the product was ribosyl-TMP, while for incorporation into nucleic acids, deoxyribosyl-TMP is required. Thus an alternative pathway is needed to explain the ability (Table 4) of mycobacteria to incorporate thymine into their nucleic acids: thymine must be first converted to thymidine by thymidine phosphorylase (Table 6), then the thymidine phosphorylated to dTMP via thymidine kinase (Table 5). In $M$. avium grown in Dubos medium the insignificant activity of thymidine kinase (Table 5) reflects its failure to incorporate exogenously supplied thymidine, but the incorporation, 


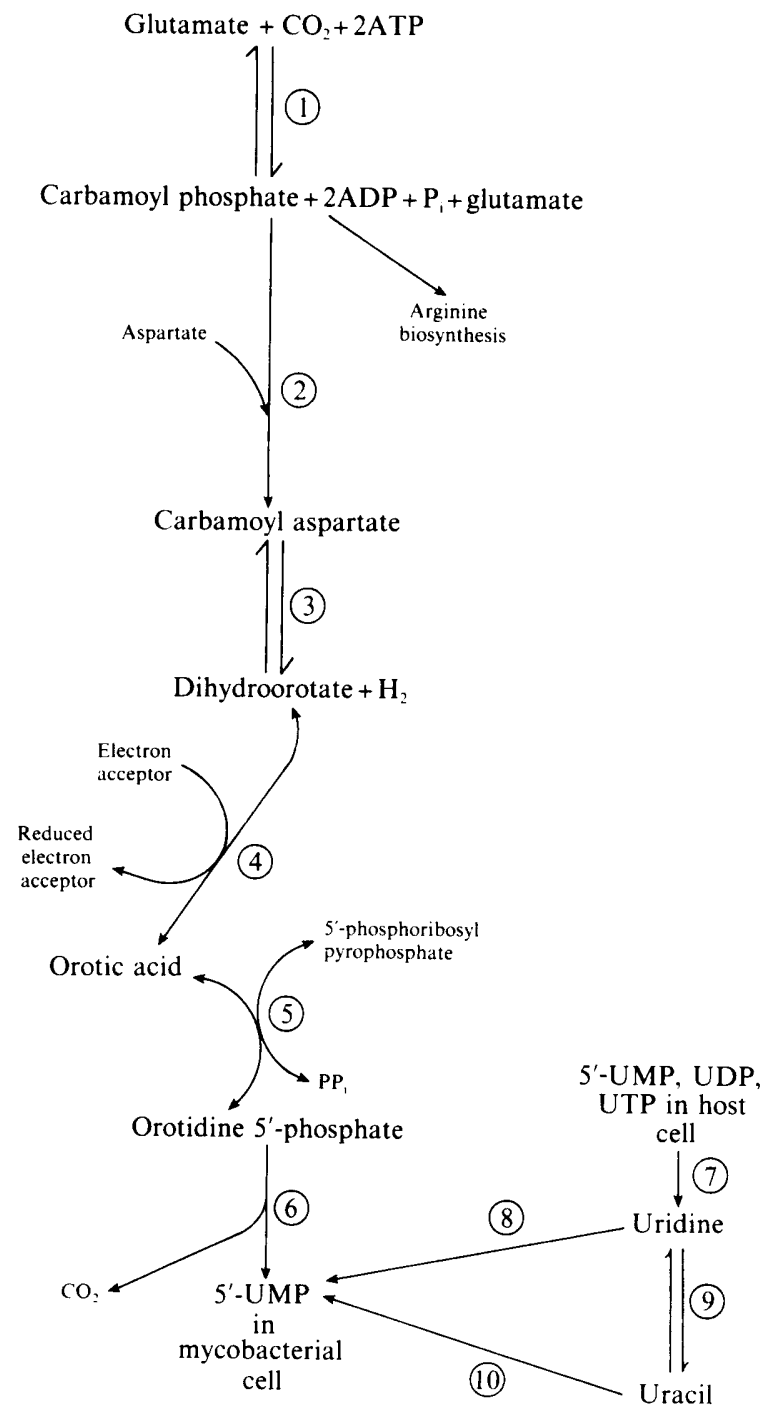

Fig. 1. Pyrimidine biosynthesis de novo and pyrimidine scavenging. Enzymes for synthesis are: 1, carbamoyl phosphate synthase; 2, aspartate transcarbamoylase; 3 , dihydroorotate synthase or dihydroorotase - this enzyme catalyses closure and thus formation of the pyrimidine ring structure $; 4$, dihydroorotate dehydrogenase $; 5$, orotate phosphoribosyltransferase; 6 , orotidine- 5 '-phosphate decarboxylase. Enzymes 2, 3 and 5 were assayed in this paper and their EC numbers are given in Methods. Enzymes 4 and 6 were sought only in $M$. leprae (Wheeler, 1989b). Enzyme 1 was not sought as the present work is restricted to enzymes unique to pyrimidine biosynthesis and scavenging. However, it has been detected in M. smegmatis (Masood \& Venkitasubramanian, 1987). Scavenging of pyrimidines with the uracil base only is shown, as it is uridine nucleotides which are the most plentiful intracellular source of the pyrimidine base. This enables the enzyme types in scavenging to be illustrated. These are: 7 , phosphatase extracellular to or on the surface of $M$. leprae; 8, nucleoside kinase; 9, nucleoside phosphorylase; 10, phosphoribosyltransferase. Mycobacteria can take up uracil and uridine but $M$. leprae cannot take up nucleotides. Details of scavenging of other pyrimidines, and their interconversions, are illustrated elsewhere (Wheeler, 1989a). at a low rate, of thymine (Table 4) suggests that some thymidine kinase activity must be present so that thymine can be converted to nucleotides. Like thymidine, thymine is incorporated into nucleic acids in both $M$. avium and $M$. microti more rapidly when they were grown in vivo than in vitro (Table 4). This appears to be related to thymidine kinase activity. Since thymidine kinase is the key enzyme in both thymidine and thymine utilization, it must have an equally limiting effect on the rate at which both these intracellular substrates are converted. However, thymine is utilized two to ten times more rapidly than thymidine. As this cannot be a result of differences in enzyme activities, it may be that mycobacteria are more permeable to thymine, as it is a more hydrophobic molecule than thymidine, which is ribosylated. Alternatively, there may be a difference in transport systems involved in their uptake, though it would be difficult to test in this system with these pathogenic mycobacteria, in which only a few thousand d.p.m. of radioactivity are incorporated over $24 \mathrm{~h}$.

Two further phosphoribosyltransferase activities were detected. Activity for cytosine was only found in $M$. microti (Table 6) and $M$. leprae. The product was identified, in extracts from both organisms, as CMP (see above). Orotate phosphoribosyltransferase activity was consistently high in all mycobacteria studied (Table 4; also Wheeler, 1989a), but exogenous orotate was not incorporated at all by $M$. avium (Table 4).

\section{Utilization of uridine nucleotides by intact mycobacteria}

So far, the results on pyrimidine scavenging have concentrated on bases and nucleosides. Yet it is uridine nucleotides which are the most plentiful source of the pyrimidine ring inside host cells, where the mycobacteria under study reside during infections. $M$. microti grown in Dubos medium, or $\mathrm{NaOH}$-treated (to abolish hostderived phosphatase) $M$. microti from mice did not take up labelled UMP or UTP.

Apparent uptake of labelled UMP or UTP by $M$. leprae, and incorporation of the label into acid-insoluble material, only occurred when considerable hydrolysis of the nucleotides to uridine was observed (Table 7). This hydrolysis was probably due to adsorption of hostderived acid phosphatase. When the phosphatase activity was inhibited by molybdate or abolished by $\mathrm{NaOH}-$ treatment (Wheeler et al., 1982), very little hydrolysis occurred. Uptake of label was insignificant compared with the variance in the results while incorporation was either zero or insignificant (Table 7). Neither $\mathrm{NaOH}-$ treatment nor addition of molybdate had any significant effect on utilization of uridine. Thus for nucleotides to be used as a source of the pyrimidine ring, the phosphate 
Table 7. Utilization of uridine nucleotides by M. leprae

Incubations were at $34^{\circ} \mathrm{C}$ and included 0.4 to $1.1 \times 10^{10}$ organisms. Two to eight incubations were done for each result using $\boldsymbol{M}$. leprae organisms isolated from two or three armadillos. Uptake and incorporation values are the percentage of radioactivity supplied that was taken up or incorporated in $24 \mathrm{~h}$ by $10^{10}$ organisms \pm SEM or range of values for zero activity. The hydrolysis values are the percentage of radioactivity supplied which was present as uridine in the incubation mixture after the bacteria had been collected by filtration calculated as hydrolysis $(\%)$ per $10^{10}$ organisms in $24 \mathrm{~h}$.

\begin{tabular}{|c|c|c|c|c|}
\hline \multicolumn{2}{|c|}{ Incubation mixture* } & \multirow{2}{*}{\multicolumn{3}{|c|}{ Activity }} \\
\hline $\mathrm{bb}$ & & & & \\
\hline$(17 \mu \mathrm{M})$ & M. leprae organism & Uptake & Incorporation & Hydrolysis \\
\hline$\left[4-{ }^{14} \mathrm{C}\right] \mathrm{UTP}$ & $\begin{array}{l}\text { Untreated } \\
\text { Untreated, + molybdate } \\
\mathrm{NaOH} \text {-treated } \\
\mathrm{NaOH} \text {-treated, + molybdate }\end{array}$ & $\begin{array}{c}0 \cdot 194 \pm 0 \cdot 024 \\
\mathrm{ND} \\
0.026 \pm 0 \cdot 022 \dagger \\
\mathrm{ND}\end{array}$ & $\begin{array}{c}0.096 \pm 0.005 \\
0.013 \pm 0.017 \dagger \\
0.031 \pm 0.021 \dagger \\
0(-0.018 \text { to } 0.020)\end{array}$ & $\begin{aligned} 44 & \pm 11 \\
8 & \pm 2 \\
0 \cdot 4 & \pm 0 \cdot 1 \\
& \text { ND }\end{aligned}$ \\
\hline$\left[\mathrm{U}-{ }^{14} \mathrm{C}\right] \mathrm{UMP}$ & $\begin{array}{l}\text { Untreated } \\
\text { Untreated, + molybdate } \\
\text { NaOH-treated }\end{array}$ & $\begin{array}{l}0 \cdot 147 \pm 0 \cdot 045 \\
0 \cdot 054 \pm 0 \cdot 002 \\
0 \cdot 123 \pm 0 \cdot 358 \dagger\end{array}$ & $\begin{array}{c}0.052 \pm 0.002 \\
0.008 \pm 0.012 \dagger \\
0(-0.027 \text { to } 0.010)\end{array}$ & $\begin{array}{l}69 \pm 12 \\
29 \pm 8 \\
3 \pm 1\end{array}$ \\
\hline$\left[5,6^{-3} \mathrm{H}\right]$ Uridine & $\begin{array}{l}\text { Untreated } \\
\text { Untreated, + molybdate } \\
\text { NaOH-treated }\end{array}$ & $\begin{array}{c}0.526 \pm 0.152 \\
\mathrm{ND} \\
0.456 \pm 0.136\end{array}$ & $\begin{array}{l}0 \cdot 390 \pm 0 \cdot 125 \\
0 \cdot 321 \pm 0 \cdot 106 \\
0 \cdot 423 \pm 0 \cdot 140\end{array}$ & $\begin{array}{l}\mathrm{NA} \\
\mathrm{NA} \\
\mathrm{NA}\end{array}$ \\
\hline
\end{tabular}

ND, Not done.

NA, Not applicable.

* Where indicated, incubation mixtures contained $10 \mathrm{~mm}$-sodium molybdate.

$\dagger$ Not significantly $(P>0.05)$ above zero.

group(s) were first removed by hydrolysis and then the nucleosides were scavenged (see Fig. 1).

\section{Discussion}

One of the most striking findings in the study of pyrimidine metabolism in pathogenic mycobacteria [here, and with $M$. leprae (Wheeler, 1989b)] is that pyrimidine biosynthesis in intact, non-growing mycobacteria is depressed when they are isolated from host tissue, yet the enzymes unique to pyrimidine biosynthesis can readily be detected in extracts of the bacteria. The detection of the enzymes in $M$. leprae clearly showed that it is capable of pyrimidine biosynthesis (Wheeler, $1989 b$ ).

The depression of synthesis of pyrimidines de novo in intact host-grown mycobacteria (Table 1) must be due to regulation of the pathway. As ATCase and DHO synthase were sometimes detected at higher activity in host-grown mycobacteria than in mycobacteria grown in Dubos medium, repression of their activities is not a plausible explanation for depression of pyrimidine biosynthesis. The activity of DHO synthase is much lower than ATCase (Table 2), but this is probably more a reflection of the enzyme assays used and may not be of significance in pyrimidine biosynthesis in intact organisms. When similar assay conditions to those used in this study were used previously, $K_{\mathrm{m}}$ values for carbamoyl aspartate (DHO synthase) and for L-aspartate (ATCase) were, respectively, $14 \mu \mathrm{M}$ and $2.75 \mathrm{~mm}$ in Pseudomonas fluorescens (Adair \& Jones, 1978) and $50 \mu \mathrm{M}$ and about $5 \mathrm{~mm}$ for Crithidia fasciculata (Kidder et al., 1976). Although $K_{\mathrm{m}}$ values for these enzymes were not obtained with the limited quantities of mycobacterial extracts available, it is likely from studies with other organisms that substrates were provided at saturating or near saturating concentrations (see also Makoff \& Radford, 1978), and that the rates in Table 2 are near maximal. However, the proportion of carbamoyl aspartate metabolized (through DHO synthase) is generally higher than the proportion of aspartate metabolized through ATCase (Table 2), and this may be as important as the maximal rates when the enzymes are functioning in intact mycobacteria, in which case DHO synthase would not be limiting the rate of pyrimidine biosynthesis. As always, caution is needed when comparing activity values between enzymes.

Repression of carbamoyl phosphate synthase cannot be ruled out as the explanation for repression of pyrimidine biosynthesis as this enzyme activity was not sought in pathogenic mycobacteria. However, no clear evidence for its repression in $M$. smegmatis was obtained in a previous study (Masood \& Venkitasubramanian, 1987) when activities varied only $2 \cdot 5$-fold in extracts of the bacteria grown on a range of nitrogen sources. These activities may have been related to growth rates (though 
growth rates were not presented). The lowest activities were in $M$. smegmatis grown with $\mathrm{NH}_{4}^{+}$as sole nitrogen source; other nitrogen sources could have been used as carbon sources as well as nitrogen sources and allowed more rapid growth of the bacteria. Certainly, repression of carbamoyl phosphate synthase in essentially a minimal medium would seem unlikely (Makoff \& Radford, 1978). In other microbes, pyrimidines usually have similar effects of repression on both carbamoyl phosphate synthase and ATCase (Makoff \& Radford 1978). This leaves repression of enzymes seeming unlikely to explain the depression of pyrimidine biosynthesis in host-grown mycobacteria though a study of their carbamoyl phosphate synthase activities would be needed to establish this point with certainty. From the present work, feedback inhibition of ATCase appears the most likely mechanism for depression of pyrimidine biosynthesis. The enzyme is almost completely inhibited by $2.5 \mathrm{mM}-\mathrm{UTP}$ and CTP, and strongly inhibited by 2.5 mM-ATP, concentrations of nucleotides which are probably reached inside mycobacterial cells. The one nucleotide whose intracellular concentration has been determined is ATP inside $M$. leprae and a 'consensus' value of $100 \mathrm{pg}$ per $10^{6}$ freshly harvested $M$. leprae has been obtained (see Barclay \& Wheeler, 1989). As $M$. leprae organisms contain $\sim 10^{-13} \mathrm{ml}$ cytoplasm each (Draper, 1982), their mean intracellular ATP concentration would be about $2 \mathrm{mM}$. Although this figure is crude, and ATCase may be exposed in situ to locally higher or lower concentrations of ATP, it illustrates that the millimolar concentrations of ATP required to inhibit ATCase can be achieved in mycobacteria - at least in $M$. leprae. When extracts were prepared, suspensions of $\sim 10^{11}$ organisms were prepared, so $1 \mathrm{ml}$ extract contained $\sim 10 \mu \mathrm{l}$ bacterial cytoplasm. Thus ATP derived from the bacteria in assays would be $0.02 \mathrm{mM}$ or less, as no attempt was made to preserve ATP during preparation of extracts. At such low concentrations, little or no inhibition of ATCase would be expected. The inhibition of ATCase by ATP is interesting because, while it occurs also (but weakly) with ATCase in pseudomonads, ATP is often an activator of bacterial ATCase (Makoff \& Radford, 1978).

Though ATCase is not repressed in mycobacteria grown in the host, it is repressed when mycobacteria are grown axenically, with a source of pyrimidine (Table 1). Such repression appears complete in $M$. avium. The explanation for this might be that a pyrimidine is constantly available in the culture medium, but not always in host cells. If this is the case, mycobacteria in host cells could respond to starvation of pyrimidines more rapidly by synthesizing pyrimidine de novo as feedback inhibition is relieved rather than by having to synthesize the enzymes for the pathway.
All the pathogenic mycobacteria studied (here, and in Wheeler, 1989a) could scavenge pyrimidines as well as synthesize them de novo. The range of exogenous pyrimidines scavenged varied from one mycobacterium to another, and appeared more extensive in host-grown organisms than organisms grown in Dubos medium.

The most plentiful source of the pyrimidine ring in host cells, uridine nucleotides (Lesse et al., 1984), could not be taken up directly by mycobacteria, though they could be hydrolysed and the uridine released taken up (see Fig. 1).

Though activity is low, thymidine incorporation in $M$. leprae has been studied most extensively (see Barclay \& Wheeler, 1989). It was stimulated 2- to 3-fold by addition of $10 \mu \mathrm{M}$-purines (see Methods) to the incubation medium (S. R. Khanolkar, personal communication), so purines are added routinely to incubation media. The rationale behind adding purines as well as a labelled pyrimidine was that the bacteria would be provided with all the bases required for nucleic acid synthesis without diluting down the supplied, labelled pyrimidine, so that rate of incorporation of labelled pyrimidine into acidinsoluble material would be maximized. Another way of enhancing the specific activity of uracil or thymidine incorporation in $M$. leprae is to use $M$. leprae in macrophages, rather than suspensions of $M$. leprae (Vejare \& Mahadevan, 1987; Wheeler, 1989a). However, suspensions of mycobacteria were used here, as so few mycobacteria can be maintained in macrophages that their total activities are less than those reported here. Thymidine incorporation was followed using $50 \mu \mathrm{M}$-thymidine. Even this concentration may not be saturating, as similar proportions of supplied thymidine were incorporated at $17 \mu \mathrm{M}, 80 \mu \mathrm{M}$ (Wheeler, 1986) and $50 \mu \mathrm{M}$ (Wheeler, 1989a) in $M$. leprae. It is important to remember that these are $24 \mathrm{~h}$ incubations; incorporations of label into acid-insoluble material is being followed, and thus uptake is more likely to be mainly facilitated diffusion rather than by any specific transport system.

The ability of intracellular mycobacteria to incorporate thymine or thymidine may account for the failure of benzylpyrimidines consistently to inhibit experimental growth of $M$. leprae in mice (Gelber, 1986), since in Escherichia coli, thymine is antagonistic to the action of trimethoprim, a benzylpyrimidine (Amyes \& Smith, 1975). However, the pharmokinetics of mice may be a more plausible explanation of the inconsistent results (Gelber, 1986; Hastings et al., 1988), particularly as mycobacteria rely on the methylation reactions interfered with by benzylpyrimidines for synthesizing many of their lipids (Minnikin, 1982), as well as synthesizing the thymine base from the uracil base.

Thymidine kinase and thymidine phosphorylase ap- 
pear to be the essential enzymes for utilization of thymine and thymidine, as thymine phosphoribosyltransferase activity cannot always be detected in mycobacteria that incorporate thymine. The kinase has been detected previously, at similarly low activity, in $M$. leprae and $M$. tuberculosis (Dhople \& Green, 1986), and in about one-quarter of the strains of mycobacteria in which it was sought when they were grown in heartinfusion broth (Saito \& Tomioka, 1984); the ability of mycobacteria to scavenge the thymine base may thus not be universal.

Phosphoribosyltransferase activity for cytosine (as well as thymine) was detected during the present studies, and appeared essential for cytosine utilization as cytosine was not converted to cytidine by mycobacteria (Table 6). The failure to detect cytosine phosphoribosyltransferase in M. microti grown in Dubos medium (which incorporate cytosine) may reflect the difficulty in assaying this activity. Both cytosine and thymine phosphoribosyltransferase activities are unusual and separate enzymes for them are not known in nature. They are likely to be associated with uracil phosphoribosyltransferase as in the protozoa Giardia lamblia and possibly Entamoeba histolytica (Hassan \& Coombs, 1988) or orotate phosphoribosyltransferase (Silva \& Hatfield, 1978). In mycobacteria, orotate phosphoribosyltransferase was detected at relatively high activities which appeared to be constitutive (Table 2). The main function of orotate phosphoribosyltransferase is probably in pyrimidine biosynthesis de novo since it is readily detectable in $M$. avium which does not incorporate exogenous orotate at all (Table 4). However, it may have a role in scavenging of cytosine and thymidine - though uracil phosphoribosyltransferase cannot be ruled out for this function until uracil and orotate phosphoribosyltransferases from mycobacteria are separated.

One of the most striking features of activities in pyrmidine scavenging is how low they are compared with activities in purine scavenging (Wheeler, 1987a, $b$ ). For instance, the most active pyrimidine nucleoside kinase, uridine kinase, is present in extracts of hostgrown mycobacteria at 7 to 70 times lower than the specific activities of adenosine kinase. This has created difficulties in interpreting some results, for instance the apparent lack of cytosine phosphoribosyltransferase in M. microti grown in Dubos medium (mentioned above). Together with the observation that biosynthetic enzymes can be detected in all mycobacteria studied, and are often detectable in extracts from cells which, when intact, do not synthesize pyrimidines de novo, this suggests that the ability of mycobacteria to scavenge pyrimidines is not so important in their nutrition as their ability to scavenge purines. This is particularly so in the case of $M$. leprae, which lacks the ability to synthesize purines itself
(Wheeler, 1987a, b) - and is thus dependent upon its ability to scavenge purines for growth - but can synthesize its own pyrimidines. Purine scavenging is more important than pyrimidine scavenging for parasites in general - some are dependent on their host for a source of both purines and pyrimidines, some for a source of purines only, but none require pyrimidines and not purines (Coombs, 1987; Hassan \& Coombs, 1988; Sherman, 1979).

I wish to thank C. Ratledge for helpful advice and Kathleen Bulmer for excellent technical assistance. Armadillos were maintained with funds from LEPRA or were obtained from the WHO (IMMLEP) bank. This investigation received financial support from the MRC and LEPRA.

\section{References}

ADAIR, L. B. \& JONES, M. E. (1978). Aspartate carbamyltransferase (Pseudomonas fluorescens). Methods in Enzymology 51, 51-58.

Amyes, S. G. B. \& SMith, J. T. (1975). Thymineless mutants and their resistance to trimethoprim. Journal of Antimicrobial Chemotherapy 1, $85-89$.

BARCLAY, R. \& WheELER, P. R. (1989). Metabolism of mycobacteria in tissues. In The Biology of the Mycobacteria, vol. 3, pp. 37-106. Edited by C. Ratledge, J. Stanford \& J. M. Grange. London: Academic Press.

Benitez. P., Medoff, G. \& Kobayashi, G. S. (1974). Rapid radiometric methods of testing susceptibility of mycobacteria and slow-growing fungi to antimicrobial agents. Antimicrobial Agents and Chemotherapy 6, 29-33.

Chadwick, M. V. (1982). Mycobacteria. Institute of Medical Laboratory Sciences Monographs. Bristol: P. S. G. Wright.

Cоомвs, G. H. (1987). Intermediary metabolism in parasitic protozoa. International Journal of Parasitology 17, 97-112.

DHOPLE, A. M. \& GREeN, K. J. (1986). Limited in vitro multiplication of Mycobacterium leprae: application to screening potential antileprosy compounds. Leprosy Review 57, suppl. 3, 149-162.

DRAPER, P. (1982). The anatomy of mycobacteria. In The Biology of the Mycobacteria, vol. 1, pp. 9-52. Edited by C. Ratledge \& J. Stanford. London: Academic Press.

GELBER, R. H. (1986). The use of rodent models in assessing antimicrobial activity against Mycobacterium leprae. Leprosy Review 57, suppl. 3, 137-148.

Hassan, H. T. \& CoOmbs, G. H. (1988). Purine and pyrimidine metabolism in parasitic protozoa. FEMS Microbiology Reviews 54, 47-83.

Hastings, R. C., Gillis, T. P., Krahenbuhl, J. L. \& Franzblan, S. G. (1988). Leprosy. Clinical Microbiological Reviews 1, 330-348.

Heyworth, P. G., Gutteridge, W. E. \& Ginger, W. E. (1984). Pyrimidine metabolism in Trichomonas vaginalis. FEBS Letters 176, $55-60$.

KidDER, G. W., Dewey, V. C. \& Nolan, L. L. (1976). Enzymes of the orotate biosynthetic pathway in Crithidia fasciculata. Canadian Journal of Biochemistry 54, 32-41.

Lesse, H. J., Biggers. J. D., Mioz, E. A. \& Lechene, C. (1984). Nucleotides in a single mammalian ovum or preimplantation embryo. Analytical Biochemistry 140, 443-448.

MAKOFF, A. J. \& RADFORD, A. (1978). Genetics and biochemistry of carbamoyl phosphate biosynthesis and its utilization in the pyrimidine biosynthetic pathway. Microbiological Reviews 42, 307-328.

Masood, R. \& Venkitasubramanian, T. A. (1987). Role of various carbon and nitrogen sources in the regulation of enzymes of pyrimidine biosynthesis in Mycobacterium smegmatis TMC 1546. Annales de Microbiologie 138, 501-507. 
MinNikin, D. E. (1982). Lipids: complex lipids, their chemistry, biosynthesis and roles. In The Biology of the Mycobacteria, vol. 1, pp. 95-185. Edited by C. Ratledge \& J. Stanford. London: Academic Press.

Mittal, A., Seshadri, P. S., Conalty, M. L., O'Sullivan, J. F. \& NATH, I. (1985). Rapid, radiometric in vitro assay for the evaluation of the anti-leprosy activity of clofazaimine and its analogues. Leprosy Review 56, 99-108.

Prasad, H. K., Singh, R. \& Nath, I. (1982). Radiolabelled Mycobacterium leprae resident in human macrophage cultures as an in vitro indicator of effective immunity in human leprosy. Clinical and Experimental Immunology 49, 517-522.

SAITo, H. \& TomiokA, H. (1984). Thymidine kinase of bacteria: activity of the enzyme in actinomycetes and related organisms. Journal of General Microbiology 130, 1863-1870.

Sathish, M., Rees, R. W. J., Seshadri, P. S. \& Nath, I. (1985). Comparison of radiometric macrophage assay and the mouse footpad infection for the evaluation of Mycobacterium leprae sensitivity or resistance to dapsone. International Journal of Leprosy 53, 378-384.

Sherman, I. W. (1979). Biochemistry of Plasmodium (malarial parasites). Microbiological Reviews 43, 453-495.

Silva, R. F. \& HatField, D. (1978). Orotate phosphoribosyltransferase: orotidylate decarboxylase (erythrocyte). Methods in Enzymology 51, 143-154

Vejare, S. \& Mahadevan, P. R. (1987). Importance of determining viability of Mycobacterium leprae inside macrophages - an in vitro method using uracil. Journal of Bioscience 11, 455-463.

WANG, C. C. \& Chang, H. W. (1984). Salvage of pyrimidine nucleotides by Trichomonas vaginalis. Molecular and Biochemical Parasitology 10, 171-184.
WhEELER, P. R. (1986). Metabolism in Mycobacterium leprae: possible targets for drug action. Leprosy Review 57, suppl. 2, 171-181.

WHEELER, P. R. (1987a). Biosynthesis and scavenging of purines by pathogenic mycobacteria including Mycobacterium leprae. Journal of General Microbiology 133, 2999-3011.

WHEELER, P. R. (1987b). Enzymes for purine synthesis and scavenging in pathogenic mycobacteria and their distribution in Mycobacterium leprae. Journal of General Microbiology 133, 3013-3018.

WheELeR, P. R. (1989a). Pyrimidine scavenging by Mycobacterium leprae. FEMS Microbiology Letters 57, 179-184.

Wheeler, P. R. (1989b). Pyrimidine biosynthesis de novo in Mycobacterium leprae. FEMS Microbiology Letters 57, 185-190.

WheEler, P. R. \& GRegory, D. (1980). Superoxide dismutase, peroxidatic activity and catalase in Mycobacterium leprae purified from armadillo liver. Journal of General Microbiology 121, 457-464.

WheEler, P. R., BHARAdWAJ, V. P. \& GRegory, D. (1982). $N$-Acetyl$\beta$-glucosaminidase, $\beta$-glucuronidase and acid phosphatase in $M y c o-$ bacterium leprae. Journal of General Microbiology 128, 1063-1071.

WORLD HEALTH ORGanization (1980). UNDP/World Bank/WHO Special Programme for Research and Training in Tropical Diseases. Report of the Fifth Meeting on the Immunology of Leprosy (IMMLEP). TDR/IMMLEP-SWG (5)/80.3, Annex 4, p. 23, Geneva: World Health Organization.

Yoshimoto, A., Amaya, T., Kobayashi, K. \& Tomita, K. (1978). Orotate phosphoribosyltransferase (yeast). Methods in Enzymology 51, 69-74. 